\title{
Front Matter: Volume 11160
}

, "Front Matter: Volume 11160," Proc. SPIE 11160, Electro-Optical Remote Sensing XIII, 1116001 (21 November 2019); doi: 10.1117/12.2555975

SPIE. Event: SPIE Security + Defence, 2019, Strasbourg, France 


\title{
PROCEEDINGS OF SPIE
}

\section{Electro-Optical Remote Sensing XIII}

\author{
Gary W. Kamerman \\ Ove Steinvall \\ Editors
}

\section{9-10 September 2019 \\ Strasbourg, France}

\author{
Sponsored by \\ SPIE \\ Cooperating Organisations \\ European Optical Society \\ Cranfield University (United Kingdom) \\ Published by \\ SPIE
}


The papers in this volume were part of the technical conference cited on the cover and title page. Papers were selected and subject to review by the editors and conference program committee. Some conference presentations may not be available for publication. Additional papers and presentation recordings may be available online in the SPIE Digital Library at SPIEDigitallibrary.org.

The papers reflect the work and thoughts of the authors and are published herein as submitted. The publisher is not responsible for the validity of the information or for any outcomes resulting from reliance thereon.

Please use the following format to cite material from these proceedings:

Author(s), "Title of Paper," in Electro-Optical Remote Sensing XIII, edited by Gary W. Kamerman, Ove Steinvall, Proceedings of SPIE Vol. 11160 (SPIE, Bellingham, WA, 2019) Seven-digit Article CID Number.

ISSN: 0277-786X

ISSN: 1996-756X (electronic)

ISBN: 9781510630239

ISBN: 9781510630246 (electronic)

Published by

SPIE

P.O. Box 10, Bellingham, Washington 98227-0010 USA

Telephone +13606763290 (Pacific Time) · Fax +1 3606471445

SPIE.org

Copyright @ 2019, Society of Photo-Optical Instrumentation Engineers.

Copying of material in this book for internal or personal use, or for the internal or personal use of specific clients, beyond the fair use provisions granted by the U.S. Copyright Law is authorized by SPIE subject to payment of copying fees. The Transactional Reporting Service base fee for this volume is $\$ 21.00$ per article (or portion thereof), which should be paid directly to the Copyright Clearance Center (CCC), 222 Rosewood Drive, Danvers, MA 01923. Payment may also be made electronically through CCC Online at copyright.com. Other copying for republication, resale, advertising or promotion, or any form of systematic or multiple reproduction of any material in this book is prohibited except with permission in writing from the publisher. The CCC fee code is 0277$786 \times / 19 / \$ 21.00$.

Printed in the United States of America by Curran Associates, Inc., under license from SPIE.

Publication of record for individual papers is online in the SPIE Digital Library.

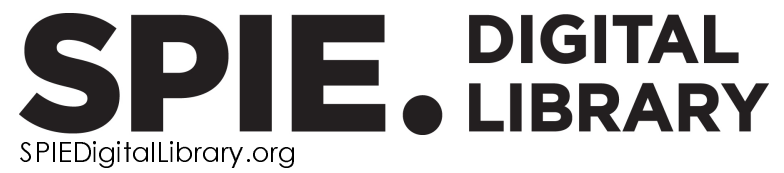

Paper Numbering: Proceedings of SPIE follow an e-First publication model. A unique citation identifier (CID) number is assigned to each article at the time of publication. Utilization of CIDs allows articles to be fully citable as soon as they are published online, and connects the same identifier to all online and print versions of the publication. SPIE uses a seven-digit CID article numbering system structured as follows:

- The first five digits correspond to the SPIE volume number.

- The last two digits indicate publication order within the volume using a Base 36 numbering system employing both numerals and letters. These two-number sets start with $00,01,02,03,04$, 05, 06, 07, 08, 09, OA, OB ... 0Z, followed by 10-1Z, 20-2Z, etc. The CID Number appears on each page of the manuscript. 


\section{Contents}

$\begin{aligned} \vee & \text { Authors } \\ \text { vii } & \text { Conference Committee }\end{aligned}$

ACTIVE IMAGING AND MAPPING

1116002 Detection and jamming resistance of quantum ghost imaging for remote sensing (Invited Paper) [1 $11160-1]$

1116003 Range-intensity profile of a SWIR laser gated-viewing system for varying temporal response of in-pixel amplification [1 $11160-2]$

1116004 Development of a novel low-cost NIR gated-viewing sensor for maritime search and rescue applications [1 $11160-3]$

1116005 Lidar-based positioning in forest environments [1 $11160-4]$

PRESENT AND PAST IMAGING RESEARCH AT ISL

111600760 years of advanced imaging at ISL: from the Cranz-Schardin camera to non-line-of-sight imaging (Invited Paper) [1 $11160-6]$

1116008 Reconstruction of density fields of supersonic flows using an improved Schlieren technique [11 $1160-7]$

1116009 Active and passive computational imaging for tracking and prediction of three-dimensional MUAV flight paths [ $111160-8]$

$111600 \mathrm{~A} \quad$ Illumination-invariant change detection for the protection of vehicle convoys [11160-9]

$11160 \mathrm{OB} \quad$ SWIR imaging through strong atmospheric turbulence: comparing a focal-plane-array camera and a compressive sensor [1 $11160-10]$

\section{TECHNOLOGY AND MEASUREMENT TECHNIQUES}

11160 OD Research on LDV stray light suppression technology based on four-wave hybrid interference [11 1160-12]

11160 OE Development of a compact gas sensor system using an ECDL by laser Raman spectroscopy [11 $1160-13]$

11160 OF Transfer learning on GPR data for IED detection in various environments [1 $1160-14$ ] 
$111600 \mathrm{D}$ Design of light receiver system for measurement of resonance Raman spectra in deep ultraviolet wavelength region [1 $11160-15]$

\section{IMAGING THROUGH SCATTERING MEDIA}

11160 Ol Underwater depth imaging using time-correlated single-photon counting at video frame rates (Invited Paper) [1 $11160-17]$

$11160 \mathrm{~J} \quad$ Optical sensing during low visibility conditions [1 $1160-18]$

SIGNAL AND IMAGE PROCESSING

11160 OK A new target identification measurement based on multi-spectral imaging [11160-19]

11160 OL Application of Sentinel-1 and Sentinel-2 data to conduct reconnaissance analyses [1 $1160-20]$

11160 OM Automatic scene understanding and object identification in point clouds [11160-21]

$111600 \mathrm{~N} \quad$ Research on image information extraction and analysis method of space-based space debris detection system [1 $11160-22]$

\section{POSTER SESSION}

$1116000 \quad$ Optimal conditions for distance determination by the range-intensity correlation methods using range-gated viewing system with nonrectangular pulses [ [ 111 l $160-24]$

11160 OR Evaluation of tunable deep UV lasers for remote identification of hazardous substances [1 11 160-27]

11160 OS Measurement of diffusion behavior of hydrogen leaked from buried pipe using Raman imaging [1 11 160-28] 


\section{Authors}

Numbers in the index correspond to the last two digits of the seven-digit citation identifier (CID) article numbering system used in Proceedings of SPIE. The first five digits reflect the volume number. Base 36 numbering is employed for the last two digits and indicates the order of articles within the volume. Numbers start with 00, 01, 02, 03, 04, 05, 06, 07, 08, 09, OA, OB...0Z, followed by 10-1Z, 20-2Z, etc.

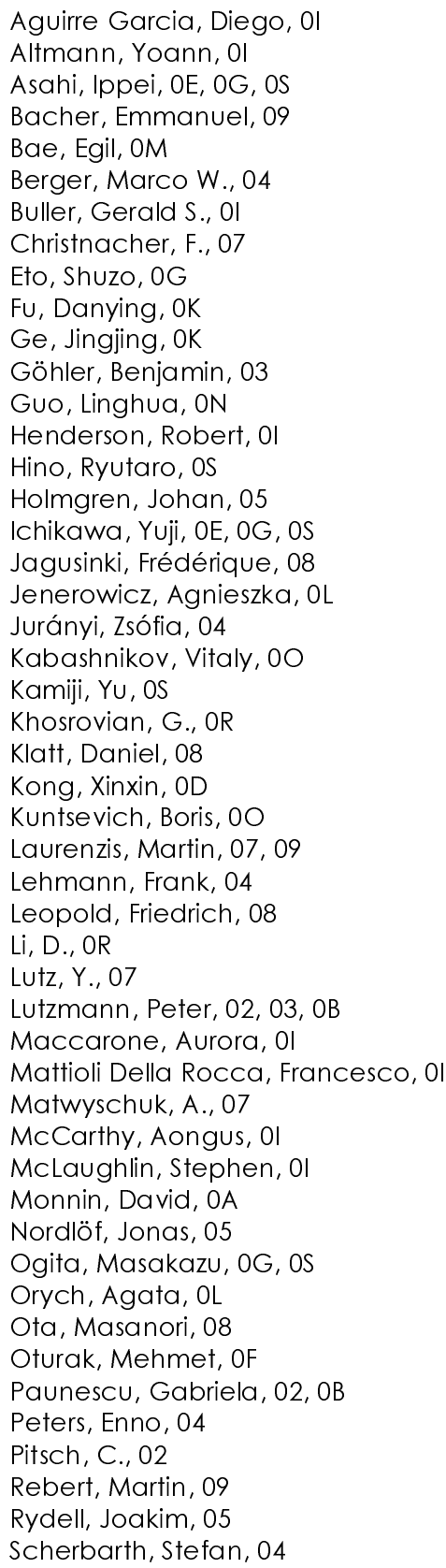


Proc. of SPIE Vol. $111601116001-6$

Downloaded From: https://www.spiedigitallibrary.org/conference-proceedings-of-spie on 26 Apr 2023 Terms of Use: https://www.spiedigitallibrary.org/terms-of-use 


\section{Conference Committee}

Symposium Chairs

Ric Schleijpen, TNO Defence, Security and Safety (Netherlands)

Karin Stein, Fraunhofer-Institut für Optronik, Systemtechnik und Bildauswertung (Germany)

Symposium Co-chair

Catherine Barrat, HGH Systèmes Infrarouges (France)

Conference Chairs

Gary W. Kamerman, Argo Al, LLC (United States)

Ove Steinvall, FOl-Swedish Defence Research Agency (Sweden)

Conference Programme Committee

Robert J. Grasso, NASA Goddard Space Flight Center (United States)

Laurent Hespel, ONERA (France)

Dennis K. Killinger, University of South Florida (United States)

Martin Laurenzis, Institut Franco-Allemand de Recherches de SaintLouis (France)

Peter Lutzmann, Fraunhofer-Institut für Optronik, Systemtechnik und Bildauswertung IOSB (Germany)

Kenneth J. McEwan, Defence Science and Technology Laboratory (United Kingdom)

Vasyl Molebny, National Taras Shevchenko University of Kyiv (Ukraine)

Gunnar Rustad, Norwegian Defence Research Establishment (Nonway)

Monte D. Turner, Air Force Research Laboratory (United States)

Session Chairs

$1 \quad$ Active Imaging and Mapping

Ove Steinvall, FOl-Swedish Defence Research Agency (Sweden)

2 Present and Past Imaging Research at ISL

Peter Lutzmann, Fraunhofer-Institut für Optronik, Systemtechnik und Bildauswertung IOSB (Germany)

3 Technology and Measurement Techniques

Martin Laurenzis, Institut Franco-Allemand de Recherches de SaintLouis (France) 
4 Imaging through Scattering Media

Gary W. Kamerman, Argo Al, LLC (United States)

$5 \quad$ Signal and Image Processing

Gary W. Kamerman, Argo Al, LLC (United States) 